\title{
Groundwater Geochemistry in El-Gallaba plain, Western Nile Valley, Egypt
}

\author{
Ahmed Gomaa ${ }^{1}$, Elsheikh E. Abdelfattah ${ }^{2}$ and Hassan S. Sabet ${ }^{1}$ \\ ${ }^{I}$ Geology Department, Faculty of Science, Al-Azhar Univ., Nasr City, Cairo, Egypt \\ ${ }^{2}$ Hydrology Department, Division of Water Resources and Desert Soil, Desert Research Center, Cairo, \\ Egypt
}

Received: 18 May 2020/ Accepted 30 July 2020 / Publication date: 30 July 2020

\begin{abstract}
The groundwater is considered as the main source for all proposes in El-Gallaba plain. Recently, the study area is a part of the Egyptian government development plan. This plan relates to concerned with the opening of Benban solar power station, which is considered as one of the largest solar power stations in the Middle East. The success of these strategies depends on the availability and reliability of basic hydrogeological, hydrologic and geochemical data. The groundwater tapping the Quaternary aquifer in the study area varies from fresh to brackish water types. Groundwater with low salinity as well as major ion concentrations have been detected in the southern side of the study area due to the hydraulic connection and mixing with the recent meteoric water and the River Nile. The higher groundwater salinity is mainly attributed to the leaching and dissolution as well as the thick clay sheets interbedded the aquifer matrix. Five hypothetical salt assemblage have been detected reflecting the impact of rock-water interaction and mixing processes on the groundwater quality. Based on the concentration of the dissolved trace and minor elements in groundwater, the aluminum concentration is less than the standard limits for human drinking $(0.2 \mathrm{ppm})$ according to the world Health Organization for drinking water quality (WHO 2007). The recorded boron and iron concentrations are marginal to the standard limits recommended for drinking and short-term for irrigation. All groundwater samples have manganese and zinc concentrations less than both drinking water and irrigation limits guidelines. Based on the results of the analyses of the major, minor and trace elements, the majority of groundwater in the study area is suitable for direct use irrigation, while it needs treatment when used for drinking purposes.
\end{abstract}

Keywords: groundwater, solar power, hydrogeological, salinity, Nile Valley

\section{Introduction}

Water is the most valuable source among the other natural resources on the earth. Although, Egypt has many fresh water sources represented by Nile River, rain water and groundwater, Egypt entered the water poverty area where the water per capita amounted to $700 \mathrm{~m}^{3} /$ year. This is due to the continuous increase of water demands during the last few decades. In Egypt, the groundwater has a special importance due to the desert conditions prevails, where desert covers about $96 \%$ of the total area. Therefore, the groundwater occurrence, assessment, management and protection are a very important issue.

El-Gallaba plain (550,000 Hectare) is one of the most important and promising areas for the development and new agricultural reclamation projects due to its location, where it locates in the in the western side of the Nile River. El-Gallaba plain could be easily reached through new Aswan-Cairo western Desert highway road. It is characterized by flat area and fertile soil. The area is very close to the Nile Valley, but none of the Nile water resources reaches it due to the big difference between the Nile elevation $(\approx+85 \mathrm{~m})$ and the floor of El-Gallaba plain elevation $(\approx+160 \mathrm{~m})$. The Nile in this area is surrounded by sharp and steep cliffs. The delay in developing such area may be attributed to the lack of information about the groundwater potentiality. Therefore, this region was not included in the governments' plan for reclamation during the last decades. Recently, a plan aiming to reclaim 220 thousand feddans in El-Gallaba plain area (West Kom Ombo) has been considered. Accordingly, the requirements for water are increasing and the groundwater reservoir could be used as a main potential source for all different activities. As a result, several strategies for groundwater exploration and development must be established to fully utilize the groundwater resources in line with the government

Corresponding Author: Ahmed Gomaa, Geology Department, Faculty of Science, Al-Azhar Univ., Nasr City, Cairo, Egypt. 
plan to develop Upper Egypt. The growth of such activity requires simultaneous strategy to well use and develop the available water resources in the study area to meet the daily and annually groundwater demands. The present study highlights the geochemical groundwater characterization in order to determine the main source(s) and distributions of the dissolved chemical constituents in the groundwater. Additionally, it aims to determine the main source(s) of groundwater recharge, discharge and flow system in the investigated groundwater aquifer.

\section{Site Description}

El-Gallaba plain is located at the southern part of the western desert immediately west of the Nile River and northwest of Aswan City where the Western Luxor-Aswan Desert Road traverses the plain. The study area is surrounded by Sin El-kaddab plateau in the west and the Nile valley in the east. In contrary, the area extends from northwest Aswan district in the south to northwest Edfu City in the north. It is geographically located between latitudes $24^{\circ} 00^{\prime}$ and $25^{\circ} 3^{\prime} 20^{\prime \prime}$ North and longitudes $32^{\circ} 15^{\prime}$ and $33^{\circ} 00^{\prime}$ East. It is enclosing an area of about $5500 \mathrm{Km}^{2}$ (Fig.1). The study area is characterized by smooth, soft surface with little undulation except some hills in the eastern side of the area. El-Gallaba plain is extended about $110 \mathrm{Km}$ length and its width varies from $25 \mathrm{Km}$ in south to $50 \mathrm{Km}$ at the middle and north with an average width of about $35 \mathrm{Km}$.

According to the Meteorological data records of Aswan station for the period 1981-2010, (The Egyptian Meteorological Authority), the study area is characterized by hot summer and warm winter. The average temperature is $26.6{ }^{\circ} \mathrm{C}$ throughout the year. The mean rainfall ranges from 0.1 to 4.3 $\mathrm{mm} /$ day. The study area is located within the desert zone, where, the maximum rainfall in one day ranges from $0.1 \mathrm{~mm} /$ day to $3.9 \mathrm{~mm} /$ day. The annual mean rainfall is $1.03 \mathrm{~mm} /$ day. This means that the contribution of the rainfall to the groundwater recharge is expected to be very small.

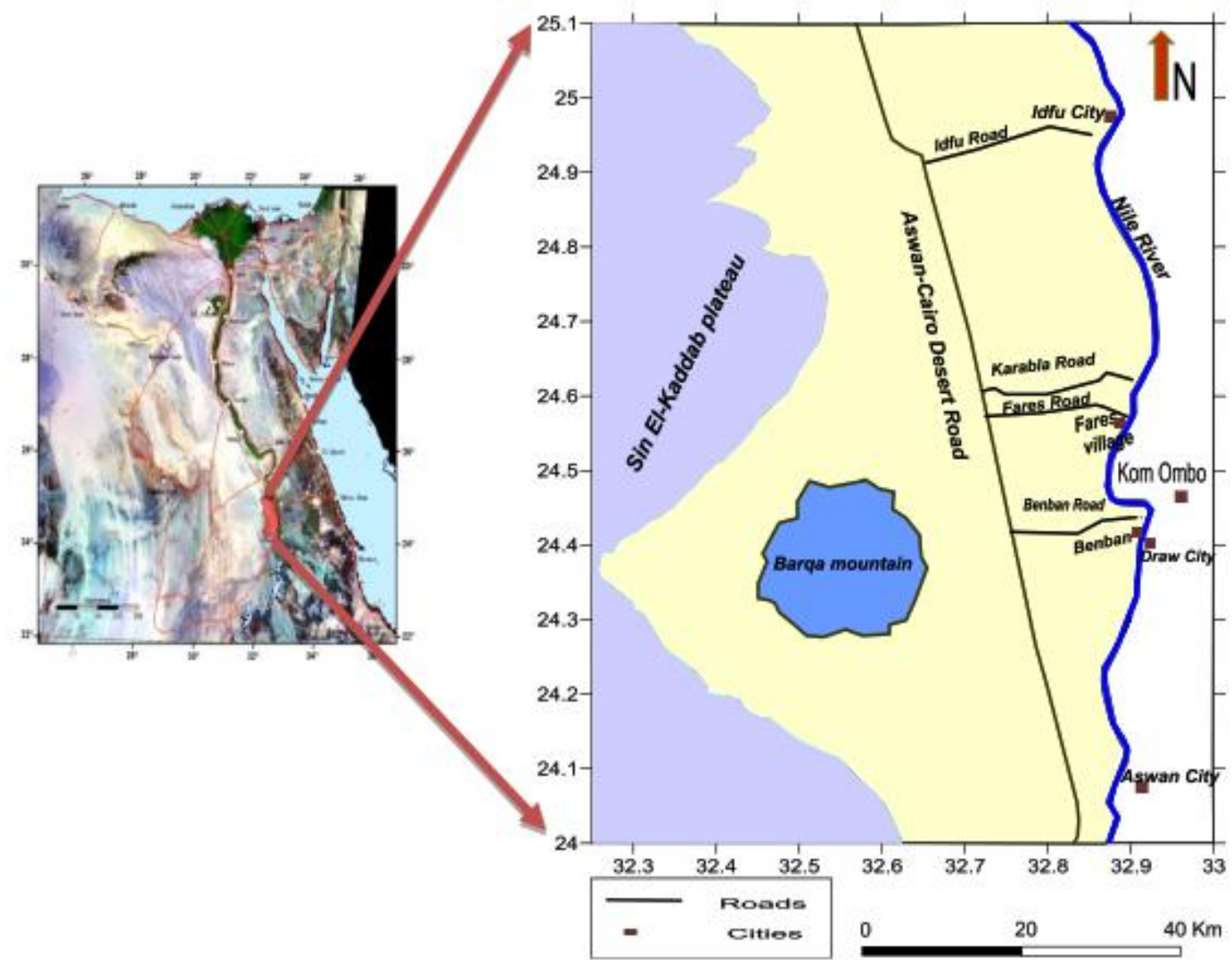

Fig. 1: Location map of the study area 


\section{Materials and Methods}

Two field trips have been conducted in El-Gallaba plain area during 2017 and 2018. The basic hydrologic data of the present drilled wells (11 observation wells and 36 productive wells) were collected during these trips. The inventory of the productive groundwater wells in El-Gallaba plain were carried out. Additionally, thirty-six groundwater samples were collected from the productive groundwater wells tapping the Quaternary aquifer besides two surface water samples from the Nile River for the purpose of hydrochemical investigation. The major chemical analyses of the collected water samples were performed in the Laboratories of the Desert Research Center (DRC) according to the methods adopted by the U.S Geological Survey and Rainwater and Thatcher, 1960. Some trace and heavy elements (Al, B, Fe, Mn, Sr and $\mathrm{Zn}$ ) were analyzed using ICP-Couple plasma using a calibrating multi standard solution.

Piper diagram (Piper, 1944) is used to understand the genetic origin of groundwater constitutes. On the bases of the groundwater chemistry, an evaluation of groundwater for drinking, domestic and irrigation uses was done.

\section{Results and Discussion}

\section{Geochemistry of Groundwater:}

In general, the chemical characteristics of groundwater are mainly influenced by rock interaction, sources of recharge, direction and rate of groundwater movements. The groundwater chemical characters of the groundwater aquifer in the study area has been evaluated based on the analytical data of representative water samples. The following physical properties including; temperature and $\mathrm{pH}$ of the groundwater samples were measured. The temperature shows a normal distribution all over the investigated area, where it ranges between 20 and $25^{\circ} \mathrm{C}$. The $\mathrm{pH}$ is ranging from 7.5 to 8.68 , indicating neutral to slightly alkaline water.

\section{Groundwater Salinity:}

The groundwater salinity reflects the geochemical composition of the groundwater. Table 1 shows the classification introduced by Todd, 1980, based on the dissolved chemical constitution in the groundwater.

The groundwater of the Quaternary aquifer in the study area varies from fresh to brackish water types (Table 1). The groundwater salinity ranges between 695 (site 10) and $5405 \mathrm{ppm}$ (site 22) with a mean value of $2195 \mathrm{ppm}$. The lower groundwater salinity in the Quaternary aquifer were detected in the western side of the study area due to the hydraulic connection with the River Nile. The higher groundwater salinity is mainly attributed to the leaching and dissolution as well as the thick clay sheets interbedded the aquifer matrix. According to (AWG, 2012), it is clear that the groundwater is suitable for agriculture, while it is mostly not suitable for drinking (WHO, 2007). It has also been observed that the salinity of some wells decreases with increasing the pumping withdrawal rate. It was also noted that the salinity of some wells increases as a result of defects in the design of these wells, as filters were put in across the layers of the shale and clay leading to an increase of the salinity of the water produced from these wells. In Figure 2, the iso-salinity contour map reveals an increase of the salinity towards the northeastern direction. This may be attributed to the recharge of groundwater with the irrigation water due to the extensive agricultural activities dominating this zone.

Table 1: Water types based on total salinity (in ppm), Todd, 1980.

\begin{tabular}{lc}
\hline Water type & Total Dissolved Solids (ppm) \\
\hline Fresh & $0-1000$ \\
Brackish & $1000-10,000$ \\
Saline & $10,000-100,000$ \\
Brine & $>100,000$ \\
\hline
\end{tabular}




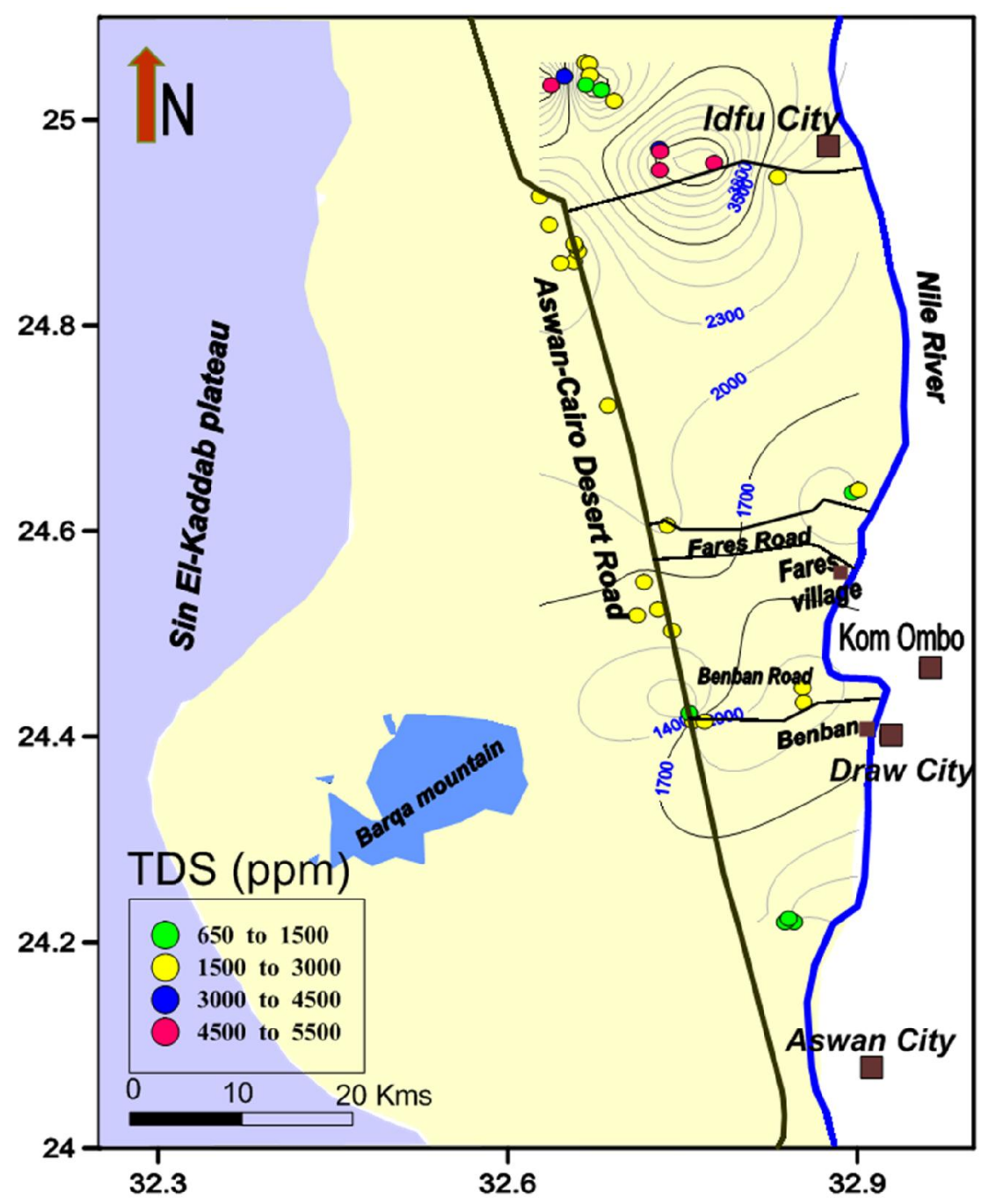

Fig. 2: Iso salinity contour map of the groundwater in the study area.

\section{Total Hardness:}

Groundwater hardness can be represented as calcium and magnesium concentrations relative to calcium carbonate. Hardness is generally expressed by the following equation:

$$
\mathrm{TH}(\mathrm{mg} / \mathrm{l})=2.4 \mathrm{Ca}(\mathrm{mg} / \mathrm{l})+4.1 \mathrm{Mg}(\mathrm{mg} / \mathrm{l})
$$

According to Sawyer and McCarty (1967), groundwater samples in the study area are classified as shown in table (2). The soft and moderately hard waters represent $25 \%$ of the total groundwater samples and are recorded in local areas. They are mainly corresponding to the fresh and fairly fresh water types. The hard and very hard groundwater samples are the dominant ( $75 \%$ of total samples). They are mainly attributed to the leaching processes of rock matrix rich in carbonate minerals as well as surface soil in the newly reclaimed areas.

Table 2: Total hardness according to Sawyer and McCarty (1967).

\begin{tabular}{llc}
\hline Total hardness as $\mathrm{CaCO}_{3}(\mathrm{mg} / \mathrm{l})$ & Water class & Percentage of the groundwater samples \\
\hline $\mathbf{7 5}$ & Soft water & $5.5 \%$ \\
$\mathbf{7 6 - 1 5 0}$ & Moderate water & $19.4 \%$ \\
$\mathbf{1 5 1 - 3 0 0}$ & Hard water & $19.4 \%$ \\
More than 300 & Very hard water & $55.5 \%$ \\
\hline
\end{tabular}




\section{Distribution of major ions:}

The major ions of the analyzed groundwater samples as well as the total salinity and some other parameters govern the chemical characters and quality of the groundwater in the study area. Their distribution pattern all over the study area is discussed as follow (Table 3 and Fig. 3):

\subsection{Distribution of sodium:}

Sodium ions content represents the main dominant cation of the analyzed groundwater in the investigated area. The sodium concentration ranges from $130 \mathrm{ppm}$ (site 34) to $1475 \mathrm{ppm}$ (site 31) (Fig. 3a). The increase of $\mathrm{Na}^{+}$ion concentration is evidently in the directions of water salinity increase, i.e. the northeastern side direction. This may be attributed to the agricultural activity and due to the presence of thick clay beds within the aquifer matrix. On the other hand, the lower concentrations of $\mathrm{Na}^{+}$ion has been recorded in the central and southern parts of the study area which may be attributed to the mixing with meteoric water origin. Since sands and clays are interbedded, groundwater and sodium may be retained longer in the less permeable strata during leaching and flushing by freshwater circulation. When such interbedded sections are penetrated by wells, water will be drawn mainly from more permeable sections at first. Long-continued withdrawals and water-table declines would be expected that alter water-circulation patterns. As a result, saline solutions could be induced to move from the clay and shale layers. When this occurs on a large scale, a substantial increase in sodium concentration of the pumped water will occur $(\mathrm{Hem}, 1989)$.

Table 3: Distribution of major ions pattern all over the study area

\begin{tabular}{lccc}
\hline Ion & Min (ppm) & Max (ppm) & Average \\
\hline $\mathbf{N a}^{+}$ & 130 & 1475 & 646 \\
$\mathbf{C a}^{+2}$ & 20 & 504 & 114.1 \\
$\mathbf{M g}$ & 2.4 & 80.2 & 34.7 \\
$\mathbf{H C O}_{3}{ }^{-}$ & 61 & 469 & 216.5 \\
$\mathbf{C l}^{-}$ & 174.9 & 1940 & 718.1 \\
$\mathbf{S O}_{4}^{-2}$ & 50 & 1802 & 563 \\
$\mathbf{T D S}$ & 695 & 5408 & 2195 \\
\hline
\end{tabular}

\subsection{Distribution of Alkalinity:}

The concentration of bicarbonate salts in the groundwater increases in the presence of the dissolved $\mathrm{CO}_{2}$ gas in groundwater, $(\mathrm{Hem}, 1989)$.

The distribution of bicarbonate in the groundwater of the study area varies between 67 in (site 26) and $469 \mathrm{ppm}$ in (site 20). This may be attributed to the considerable recharge comes from meteoric water. Carbonate represents the least dominant anion in the study area (Fig. 3b).

\subsection{Distribution of sulphate:}

The solubility of calcium sulphate increases greatly in the presence of sodium chloride from about $1500 \mathrm{ppm} \mathrm{SO}_{4}{ }^{2-}$ (in pure water) to extent of $5800 \mathrm{ppm} \mathrm{SO}_{4}{ }^{2-}$ in a saturated solution of sodium chloride (Atwa, 1979).

The concentration of sulphate ranges between $50 \mathrm{ppm}$ in (site 10) and $1802 \mathrm{ppm}$ in (site 33) (Fig. $3 c$ ). The Sulphate content increases towards northeastern direction (as a result of agriculture activity). The change in $\mathrm{SO}_{4}{ }^{2-}$ content is directly proportional to the total salinity content.

\subsection{Distribution of chloride:}

Chloride ion represent the major anion in the groundwater samples of the study area. Chloride ion is presented in all-natural water with a concentration ranging between $3 \mathrm{ppm}$ in rainwater and 19,000 ppm in sea water (Correns, 1956). In the study area, the chloride content varies between $174.9 \mathrm{ppm}$ (site 34) and $1940 \mathrm{ppm}$ (site 31 ). The change in chloride content is directly proportional to the total salinity content (Fig. 3d).

The factors govern the concentration of chloride include the leaching and dissolution of the intercalated clay and shale beds as well as rock water interaction and the degree of mixing with different water bodies such as the upward leakages from the underneath Nubian aquifer. Additionally, the surface 
water recharge from the Nile River associated with the irrigation canals as well as the irrigation processes in the new reclaimed lands located to the east and the south.
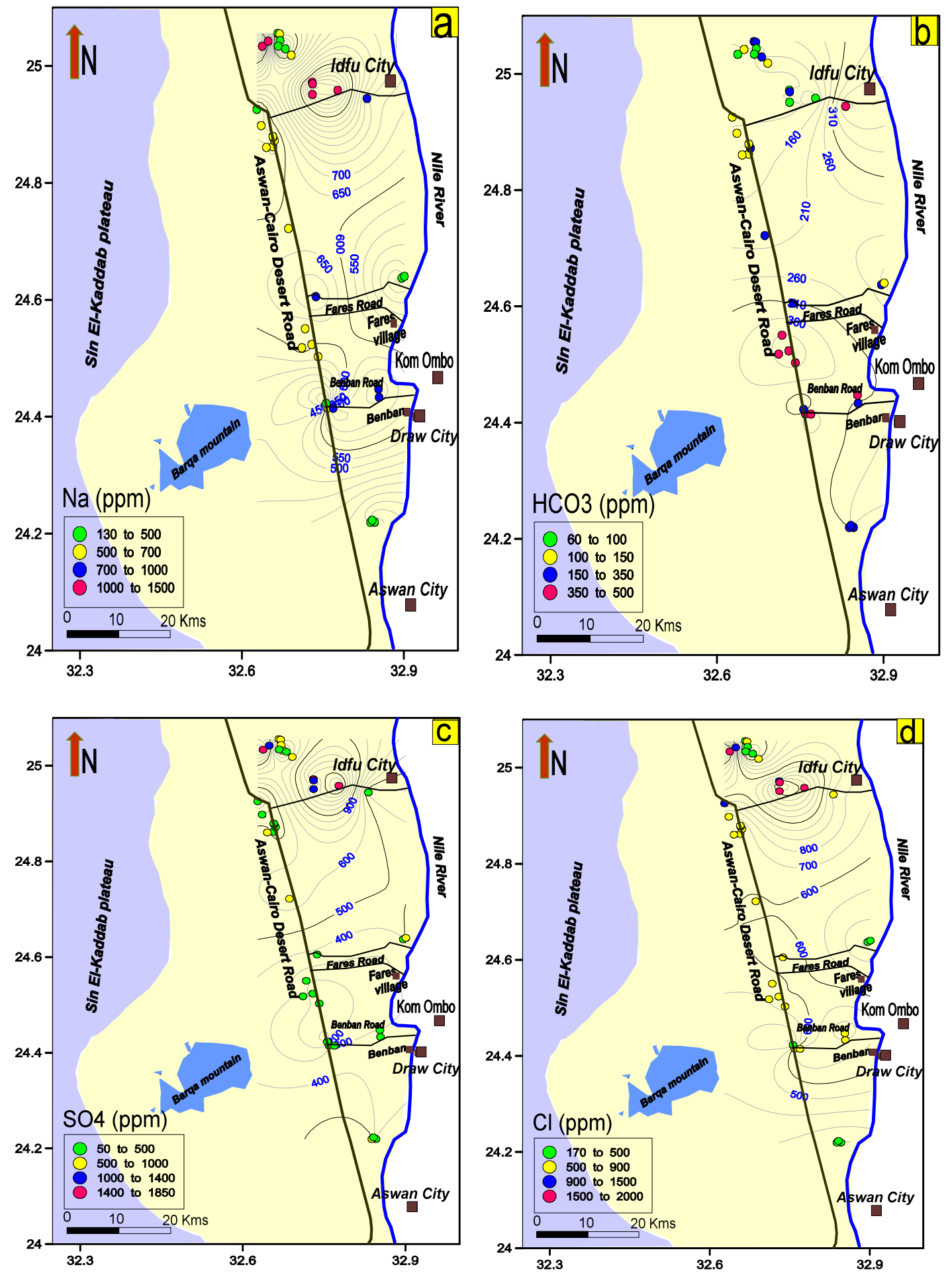

Fig. 3: Distribution of major ions in the groundwater of the study area. 


\subsection{Hypothetical salt assemblages:}

The combination between major ions is well illustrated by the bar graphs outlined by Palmer (1911). The cations are represented in terms of equivalent mole percentages reacting values in the left column and the anions in the right column. As a result of combination between cations and anions, the hypothetical salts are formed. The groundwater samples have been classified into five assemblages' groups (Table 4). This table shows the following remarks:

The groundwater of the different reveals the different percentages of salts assemblage due geochemical processes affecting the groundwater quality including; mixing, cations exchange capacity as well as rock-water interaction.

a- The salt combination assemblages Groups I, II \& III have been recorded in the central and eastern parts of the study area which are rich with carbonates and terrestrial $\mathrm{Na}_{2} \mathrm{SO}_{4}$ salts, reflecting a recent meteoric water recharge that infiltrates from Nile River to the shallow groundwater aquifers.

b- Salt combination assemblage Groups IV and V indicate the final stage of groundwater maturity due to the impact of rock water interaction that characterizes the groundwater of the Northern part (Wells 21\& 16).

Table 4: Hypothetical salt assemblages for groundwater samples of the study area.

\begin{tabular}{|c|c|c|}
\hline Hypothetical salt assemblages group & Sample No. & $\begin{array}{l}\text { Percentage } \\
\text { of samples }\end{array}$ \\
\hline $\begin{array}{l}\mathrm{I}-\mathrm{NaCl}, \underset{\mathrm{Na}}{\mathrm{Ca} \mathrm{SO}_{4},} \mathrm{NaHCO}_{3}, \quad \mathrm{Mg} \quad\left(\mathrm{HCO}_{3}\right)_{2} \text { and } \\
\mathrm{Ca}(\mathrm{HCO})_{2}\end{array}$ & $\begin{array}{l}\text { 1,2,3,4,5,8,9,10,20,6,7 and (Nile1, } \\
\text { Nile2) }\end{array}$ & $30.5 \%$ \\
\hline $\begin{array}{l}\mathrm{II}-\mathrm{NaCl}, \mathrm{Na}_{2} \mathrm{SO}_{4}, \mathrm{MgSO}_{4}, \mathrm{Mg}\left(\mathrm{HCO}_{3}\right)_{2} \text { and } \mathrm{Ca} \\
(\mathrm{HCO})_{2}\end{array}$ & 34 and 35 & $5.5 \%$ \\
\hline III-NaCl, $\mathrm{Na}_{2} \mathrm{SO}_{4}, \mathrm{MgSO}_{4}, \mathrm{CaSO}_{4}$ and $\mathrm{Ca}\left(\mathrm{HCO}_{3}\right)_{2}$ & $\begin{array}{l}11,12,13,14,15,17,18,19,22,23,24 \\
25,26,27,28,29,30,31,32,33 \text { and } 36\end{array}$ & $58 \%$ \\
\hline $\begin{array}{l}\mathrm{IV}-\mathrm{NaCl}, \mathrm{MgCl}_{2}, \mathrm{MgSO}_{4}, \mathrm{Mg}\left(\mathrm{HCO}_{3}\right)_{2} \text { and } \mathrm{Ca} \\
\left(\mathrm{HCO}_{3}\right)_{2}\end{array}$ & 21 & $3 \%$ \\
\hline $\mathrm{V}-\mathrm{NaCl}, \mathrm{Na}_{2} \mathrm{SO}_{4}, \mathrm{MgSO}_{4}$, and $\mathrm{Ca}\left(\mathrm{HCO}_{3}\right)_{2}$ & 16 & $3 \%$ \\
\hline
\end{tabular}

\subsection{Piper trilinear diagram:}

Piper diagram (1944), constitutes a useful tool in water analysis interpretation, and is considered as one of the most widely used diagram for natural groundwater classification. This type of diagrams consists of three separate fields for plotting the chemical data; two triangles at the lower right and lower left side sand an intervening diamond shape for sample projection. The major cations $\left(\mathrm{Ca}^{2+}+\mathrm{Mg}^{2+}\right.$ and $\mathrm{Na}^{+}+\mathrm{K}^{+}$) expressed in percentage equivalent per million are plotted in the lower left triangle, while the major anions $\left(\mathrm{Cl}^{-}+\mathrm{SO}_{4}{ }^{2-}\right.$ and $\left.\mathrm{CO}_{3}{ }^{2-}+\mathrm{HCO}_{3}{ }^{-}\right)$expressed in the same unit are plotted in the lower right triangle. The two points representing the cations and anions composition, then projected on the diamond shaped field. Distinct groundwater quality types can be easily distinguished by the plotting in certain sub-areas of the diamond shaped field (Fig.4). The analyzed data of the groundwater samples are classified as follows:

a- Most of Groundwater samples (91.5\%) are located in sub-area 7, reflecting primary salinity, i.e. noncarbonate alkali exceeds $50 \%$ as a result of recharging from Nile River and may be attributed to clay lenses.

b- Wells nos. W34, W35 and W36 (8.5\% of the Groundwater samples) are located in sub-area 9, i.e. no one of the cation-anion pairs in the classification exceeds $50 \%$ due to its mixing water. 


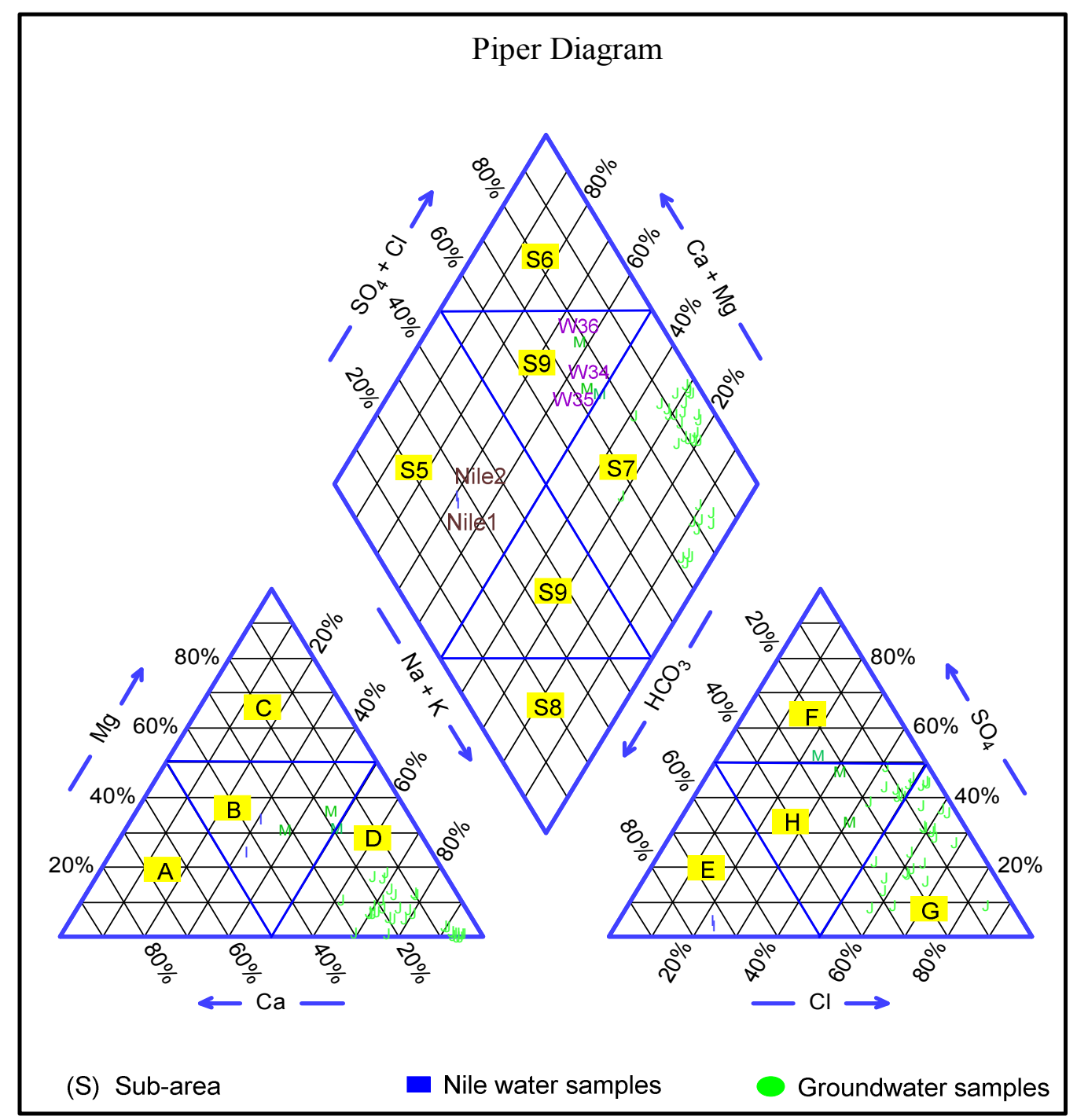

Fig. 4: Piper diagram classification

\subsection{Geochemistry of minor and trace elements}

Water is essential to sustain life, and a satisfactory (adequate, safe and accessible) supply must be available to all. Improving access to safe drinking water can result in tangible benefits to health. Rare elements and heavy metals are one of the most important issues with water use. The minerals that may exist in the water represent health risks that cannot be underestimated for humans and animals, as they may affect crops which irrigated with this water. In most cases, these metals accumulate in the crops and harmful effects can occur to humans or the animals that eat them. Therefore, the World Health Organization has determined the recommended limits for these metals in drinking water. In 1983-1984 and in 1993-1997, the World Health Organization (WHO) published the first and second editions of the guidelines for drinking water, the most updated edition published in 2007. On the other hand the recommended limits for these metals in irrigation have been determined by the Australian guidelines for irrigation water quality (AWG 2012). The concentration of heavy metal constituents in groundwater samples collected in 2018 is shown in (Table 5) and is represented in Figure (5). In Figure 5 , the box plot shows that all groundwater samples (except sample of well no.3) have aluminum concentrations less than the standard limits guidelines for human drinking $(0.2 \mathrm{ppm})$ according to the world Health Organization for drinking water quality (WHO 2007). It is also less than the recommended limits for the short-term irrigation $(5 \mathrm{ppm})$ according to the Australian guidelines for irrigation water quality (AWG 2012) in most of groundwater samples (Table 4). Four groundwater samples (W22, W31, W32 and W33) have boron concentrations marginal to the standard limits 
recommended for drinking water (WHO 2007), but two groundwater samples only (W22 and W33) have boron concentrations marginal to the recommended limits for the short-term irrigation (AWG 2012). Two groundwater samples (W3 and W11) have iron concentrations marginal to the standard limits recommended for drinking water (WHO 2007), while all groundwater samples have iron concentrations less than the recommended limits for the short-term irrigation (AWG 2012). All groundwater samples have manganese and zinc concentrations less than both drinking water and irrigation limits guidelines.
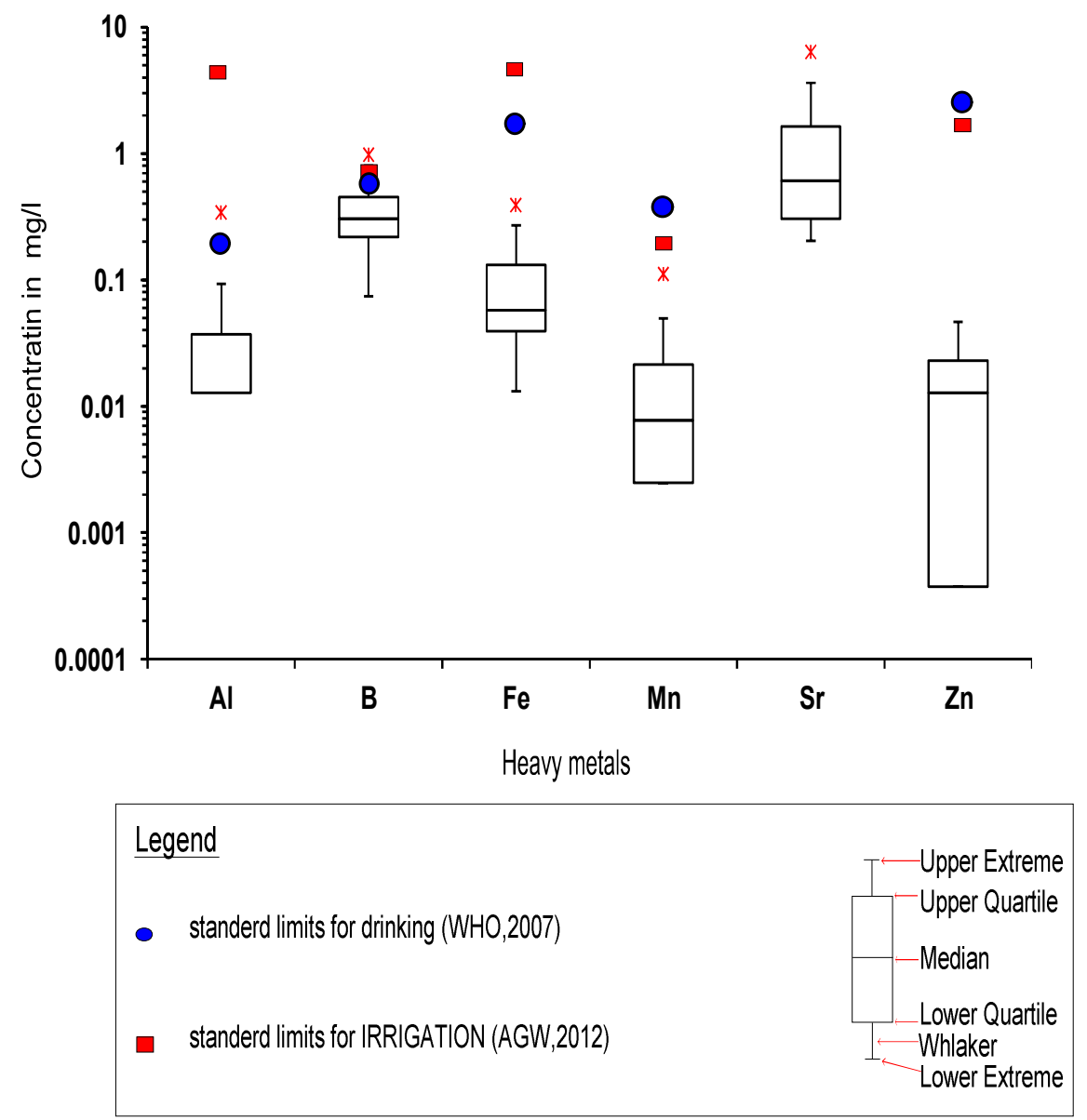

Fig. 5: Box plots showing distribution of some trace elements.

Table 5: Recommended standard limits for drinking and irrigation water

\begin{tabular}{ccc}
\hline Metal & $\begin{array}{c}\text { Standard limit for drinking } \\
(\mathbf{p p m})(\text { WHO 2007) }\end{array}$ & $\begin{array}{c}\text { Standard limit for irrigation (ppm) } \\
\text { (AWG 2012) }\end{array}$ \\
\hline Al & 0.2 & 5.0 \\
B & 0.5 & 0.75 \\
Fe & 3.0 & 5.0 \\
Mn & 0.4 & 0.2 \\
Zn & 3.0 & 2.0 \\
\hline
\end{tabular}

\section{Conclusion}

The groundwater of the Quaternary aquifer that constitute the main water-bearing formation in the study area varies from fresh to brackish water types. The groundwater salinity ranges between 695 and $5405 \mathrm{ppm}$ with a mean value of $2000 \mathrm{ppm}$. The lower groundwater salinity in the Quaternary aquifer were detected in the western side of the study area due to the hydraulic connection with the River Nile. The higher groundwater salinity is mainly attributed to the leaching and dissolution as well as the thick 
clay sheets interbedded the aquifer matrix. The soft and moderately hard waters represent $25 \%$ of the total groundwater samples and are recorded in local areas. They are mainly corresponding to the fresh and fairly fresh water types. The hard and very hard groundwater samples are the dominant $(75 \%$ of total samples). They are mainly attributed to the leaching processes of rock matrix rich in carbonate minerals in the newly reclaimed areas. The salt combination assemblages Groups I, II \& III were recorded in the central and eastern parts of the study area which are rich with carbonates and $\mathrm{Na}_{2} \mathrm{SO}_{4}$ salts. This reflects a recent meteoric water recharge that infiltrates from Nile River to the shallow groundwater aquifer. It is clear that the groundwater is suitable for agriculture, while is mostly not suitable for drinking. It has also been observed that the salinity of some wells decreases with increasing the pumping withdrawal rate. The aluminum concentrations in all groundwater samples is less than the standard limits guidelines for human drinking $(0.2 \mathrm{ppm})$ according to the world Health Organization for drinking water quality. It is also less than the recommended limits for the short-term irrigation (5 $\mathrm{ppm}$ ) according to the Australian guidelines for irrigation water quality in most of groundwater samples. The boron and iron concentrations at certain sites are marginal to the standard limits recommended for drinking water and many sites have boron concentrations marginal to the recommended limits for the short-term irrigation. All groundwater samples have manganese and zinc concentrations less than both drinking water and irrigation limits guidelines. The groundwater in El-Gallaba Plain is good water for sustainable agricultural development and purification (treatment and/or desalination) is urgent for human drinking and domestic uses.

\section{References}

Atwa, S.M.M., 1979. Hydrogeology and Hydrogeochemistry of the North Western Coast of Egypt, Ph. D. Thesis, Fac. of Sc., Alexandria Univ., 156.

AWG, 2012. Australian Water Guidelines for irrigation, the State of Queensland. Department of Environment and Heritage Protection.https://www.ehp.qld.gov.au/water/guidelines/,2012-2018.

Correns, C.W., 1956. The geochemistry of the halogens in physics and chemistry of the earth, Edited by L.A. Ahrens et al., Mc-Graw-Hill, London, 181.

Hem, J.D., 1989. Study and Interpretation of the Chemical Characteristics of Natural Water. U.S.G.S.Water-Supply Paper 2254. US Government Printing Office, Washington.

Palmer, C., 1911. The geochemical interpretation of water analysis, V.S. Geol. Surv., 470-490.

Piper, A.M., 1944. A graphic procedure in the geochemical interpretation of water analysis, Am. Geophys., Union. Trans., 25: 414-923.

Rainwater, F.R. and L.L. Thatcher, 1960. Methods for collection and analysis of water samples. V.S.G.S. water supply, paper No. 1454: 301.

Sawyer, C.N., and P.L. McCarty, 1967. Chemistry for sanitary engineers, Mc-Graw Hill, New York, 518.

The Egyptian Meteorological Authority, Meteorological data records of Aswan station for the period 1981-2010.

Todd, D. K., 1980. Groundwater hydrology. John Wiley and Sons, Inc., New York, U.S.A., 535.

World Health Organization (WHO), 2007. Guideline for drinking water quality. Recommendation vol. 4th ed. 36 . 